\title{
Analisis belanja daerah pada Kabupaten Induk dalam Provinsi Jambi
}

\section{Bagas Pradyastio*; Selamet Rahmadi; Yohanes Vyn Amzar}

Prodi Ekonomi Pembanguan Fak. Ekonomi dan Bisnis Universitas Jambi

*E-mail korespondensi: pradyastiobagas@gmail.com

\begin{abstract}
This study aims to determine whether economic growth, population, and local original income affect regional spending in the Main District in Jambi Province. The data used in this study are secondary data for 5 years, namely from 2012 to 2016. The variables used are regional expenditure, economic growth, population, and locally-generated revenue(PAD) in Parent Regencies in Jambi Province. The analytical tool used in this study is a simple linear regression and multiple linear regression using panel data. The results of data processing obtained the following results. First, economic growth does not significantly influence regional spending. Second, the population has a significant influence on regional spending. Third, the PAD has a significant effect on regional expenditure. Fourth, when viewed together it can be concluded that only PAD has a positive and significant effect, while economic growth and population do not affect regional spending in Parent Regencies in Jambi Province.
\end{abstract}

Keywords: Regional expenditure, Economic growth, Total population, locally-generated revenue $(P A D)$

\begin{abstract}
Abstrak
Penelitian ini bertujuan untuk mengetahui apakah pertumbuhan ekonomi, jumlah penduduk, dan pendapatan asli daerah berpengaruh terhadap belanja daerah di Kabupaten Induk yang ada di Provinsi Jambi. Data yang digunakan dalam penelitian ini adalah data sekunder selama 5 tahun yaitu dari tahun 2012 hingga tahun 2016. Variabel yang digunakan adalah belanja daerah, pertumbuhan ekonomi, jumlah penduduk, dan pendapatan asli daerah (PAD) di Kabupaten Induk di Provinsi Jambi. Alat analisis yang digunakan pada penelitian ini adalah regresi linier sederhana dan regresi linier berganda dengan menggunakan data panel. Hasil pengolahan data diperoleh hasil sebagai berikut. Pertama, pertumbuhan ekonomi tidak berpengaruh signifikan terhadap belanja daerah. Kedua, Penduduk memiliki pengaruh signifikan terhadap belanja daerah. Ketiga, PAD berpengaruh secara signifikan terhadap belanja daerah. Keempat, apabila dilihat secara bersama-sama dapat disimpulkan bahwa hanya PAD yang berpengaruh positif dan signifikan, sedangkan pertumbuhan ekonomi dan jumlah penduduk tidak mempengaruhi belanja daerah di Kabupaten Induk di Provinsi Jambi.
\end{abstract}

Kata kunci: Belanja daerah, pertumbuhan ekonomi, jumlah penduduk, pendapatan asli daerah (PAD)

\section{PENDAHULUAN}

Otonomi daerah merupakan suatu pemberian hak dan kewajiban kepada daerah dalam menyelenggarakan pemerintahan, kewenangan tersebut diberikan secara profesional yang diwujudkan dengan peraturan, pembagian, dan pemanfaatan sumber 
daya nasional yang berkeadilan, serta pembagian-pembagian keuangan pusat dan daerah sesuai dengan ketetapan MPR Republik Indonesia. Otonomi daerah disatu sisi memberikan kewenangan yang luas kepada pemerintah daerah, namun disisi lain memberikan tanggung jawab yang lebih besar bagi pemerintah daerah dalam upaya peningkatan kesejahteraan masyarakat. Pemerintah daerah mengalokasikan dana dalam bentuk anggaran belanja daerah dalam APBD untuk menambah aset tetap.

Pemberian otonomi dan tanggung jawab yang lebih besar dari pemerintah pusat kepada pemerintah daerah dimaksudkan untuk membantu pemerintah pusat dalam penyelenggaraan pemerintah pada umumnya. Disamping itu, tujuan lain dari pemberian otonomi daerah adalah untuk mengurangi ketergantungan pemerintah daerah terhadap pemerintah pusat terutama dalam masalah keuangan, sehingga daerah diharapkan mampu membiayai keuangannya secara mandiri dan juga untuk meningkatkan pelayanan publik, meningkatkan efisiensi, dan meningkatkan kesejahteraan rakyat. Oleh karena itu pemerintah daerah diharapkan mengelola keuangan daerahnya secara efisien dan efektif sehingga tujuan desentralisasi maupun tujuan daerah yang telah ditetapkan seperti pertumbuhan ekonomi, pemerataan pendidikan, meningkatnya PAD dapat dicapai.

Menurut penelitian Pambudi (2007) belanja juga dapat dikategorikan menurut karakteristiknya menjadi dua bagian, yaitu belanja selain modal (belanja administrasi umum; belanja operasi, pemeliharaan sarana dan prasarana publik; belanja transfer; belanja tak terduga) dan belanja modal. Saragih (2003) menyatakan bahwa pemanfaatan belanja hendaknya dialokasikan untuk hal-hal produktif, misal untuk melakukan aktivitas pembangunan. Belanja Daerah di masing masing daerah sangat dipengaruhi kemampuan daerah dalam menggali sumber-sumber keuangan sendiri agar dapat meningkatkan pendapatan bagi daerah dan pertumbuhan ekonomi.

Menurut Sukirno (2006) pertumbuhan ekonomi merupakan perubahan tingkat kegiatan ekonomi yang berlaku dari tahun ke tahun, sehingga untuk mengetahuinya harus diadakan perbandingan pendapatan naional dari tahun ke tahun, yang dikenal dengan laju pertumbuhan ekonomi. Kenaikan dan penurunan pertumbuhan ekonomi daerah dapat ditentukan dari komposisi pengeluaran pemerintah. Peningkatan pertumbuhan ekonomi daerah akan berpengaruh pada belanja daerah yang akan dikeluarkan oleh pemerintah karena dengan meningkatnya perekonomian, fasilitas-fasilitas umum yang dibutuhkan oleh masyarakat akan meningkat, seperti sekolah, jalan raya, rumah sakit dll.

Dalam penentuan kebijakan pemerintah, jumlah penduduk juga merupakan salah satu faktor yang mempengaruhi pengeluaran belanja daerah. Karena meningkatnya jumlah penduduk menuntut adanya peningkatan sarana dan prasarana umum, baik dari aspek kuantitas maupun kualitas. Jumlah penduduk yang besar bagi pemerintah daerah oleh para perencana pembangunan dipandang sebagai asset modal dasar pembangunan tetapi sekaligus juga sebagai beban pembangunan.

Identifikasi sumber Pendapatan Asli Daerah adalah meneliti, menentukan dan menetapkan mana sesungguhnya yang menjadi sumber Pendapatan Asli Daerah dengan cara meneliti dan mengusahakan serta mengelola sumber pendapatan tersebut dengan benar sehingga memberikan hasil yang maksimal (Elita, 2007). Usaha untuk menggali sumber-sumber Pendapatan Asli Daerah (PAD) sebagai salah satu sumber pembiayaan penyelenggaraan kewenangan harus didukung oleh potensi ekonomi yang dimiliki daerah sebagai basis PAD. Hal ini disebabkan karena kemampuan masyarakat untuk membayar pajak dan retribusi kepada daerah sangat tergantung kepada aktivitas ekonomi yang mereka lakukan. Semakin tinggi kegiatan ekonomi yang dilakukan oleh masyarakat, 
maka akan meningkatkan pendapatan yang dapat mereka terima dan usaha daerah untuk meningkatkan PAD melalui pajak daerah dan retribusi daerah dapat ditingkatkan.

Di Provinsi Jambi terdapat 5 kabupaten induk anatara lain Kabupaten Batanghari, Kabupaten Bungo, Kabupaten Merangin, Kabupaten Tanjung Jabung barat, dan Kabupaten Kerinci. Saat ini belanja daerah dari tahun ke tahun dapat dikatakan selalu meningkat, hanya di Kabupaten Bungo pada tahun 2016 mengalami penurunan. Belanja daerah Kabupaten Batanghari pada tahun 2015 tercatat sebesar Rp. 1.036.707.669.047,00 lalu pada tahun 2016 meningkat menjadi Rp. 1.140.556.364.746,00. Sedangkan di kabupaten Bungo terjadi penurunan pada tahun 2016 menjadi sebesar Rp. 1.174.216.297.589,00 yang sebelumnya adalah sebesar Rp. 1.259.935.359.967,00 pada tahun 2015. Belanja Daerah Kabupaten Merangin pada tahun 2015 sebesar Rp. 1.064.467.262.391,02 lalu meningkat menjadi Rp. 1.377.598.204.653,47 pada tahun 2016. Pada Kabupaten Tanjung Jabung Barat Belanja Daerah tercatat sebesar Rp. 1.115.044.670.015,00 pada tahun 2015 lalu meningkat menjadi Rp. 1.574.888.399.213,00 pada tahun 2016. Lalu di Kabupaten Kerinci nilai Belanja Daerah pada tahun 2015 sebesar Rp. 1.041.825.614.167,93 dan meningkat menjadi Rp. 1.183.983.229.604,00 pada tahun 2016.

Peningkatan belanja daerah pada tahun 2015-2016 juga diiringi dengan meningkatnya pertumbuhan ekonomi, jumlah penduduk, dan PAD. Pertumbuhan ekonomi di 5 kabupaten induk di Provinsi Jambi pada tahun 2015-2016 dapat dikatakan selalu meningkat, hanya pada kabupaten Tanjab Barat yang pertumbuhan ekonominya mengalami penurunan sebesar 0,63\%. Untuk jumlah penduduk, tiap-tiap daerah selalu mengalami peningkatan. Pertambahan jumlah penduduk tertinggi terjadi di kabupaten Bungo pada tahun 2016 meningkat sebesar kurang lebih 7000 jiwa. Untuk PAD di 5 kabupaten induk di Provinsi Jambi, dari data yang tersedia, hanya pada kabupaten Batanghari dan kabupaten Merangin yang mengalami penurunan jumlah PADnya, sedangkan di daerah lain selalu mengalami peningkatan dari tahun 2015 ke tahun 2016.

Berdasarkan data dan latar belakang tersebut penelitian ini bertujuan untuk menganalisis: 1) Bagaimana pengaruh pertumbuhan ekonomi terhadap belanja daerah pada 5 kabupaten induk di Provinsi Jambi. 2) Bagaimana pengaruh jumlah penduduk terhadap belanja daerah pada 5 kabupaten induk di Provinsi Jambi. 3)Bagaimana pengaruh PAD terhadap belanja daerah pada 5 kabupaten induk di Provinsi Jambi. 4) Bagaimana pengaruh pertumbuhan ekonomi, jumlah penduduk, dan PAD terhadap belanja daerah pada 5 kabupaten induk di Provinsi Jambi.

\section{METODE}

\section{Jenis dan sumber data}

Jenis data yang digunakan dalam penelitian ini adalah data sekunder antara lain adalah data belanja daerah, pertumbuhan ekonomi, jumlah penduduk, dan PAD. Penelitian ini akan menggabungkan antara data runtun waktu (time series) dan data silang (cross section) yang disebut dengan regresi menggunakan data panel. Data yang digunakan dalam penelitian ini diperoleh dari buku Kabupaten Dalam Angka untuk di 5 Kabupaten Induk yang ada di Provinsi Jambi. 5 Kabupaten yang dimaksud antara lain adalah Kabupaten Batanghari, Kabupaten Bungo, Kabupaten Merangin, Kabupaten Tanjung Jabung Barat, dan Kabupaten Kerinci. Buku Dalam Angka tiap Kabupaten diterbitkan oleh Badan Pusat Statistik dan data didapatkan dengan melakukan pencatatan secara langsung di kantor BPS. 


\section{Metode analisis data}

Sesuai tujuan penelitian yang akan dicapai, maka penelitian ini menggunakan analisis regresi linier sederhana dan analisis regresi linier berganda dengan menggunakan data panel. Analisis regresi dengan menggunakan data panel adalah suatu metode mengenai gabungan dari data runtun waktu dengan data silang. Untuk menggambarkan data panel secara singkat, misalkan pada data cross section, nilai dari satu variabel atau lebih dikumpulkan untuk beberapa unit sampel pada suatu waktu. Dalam data panel, unit cross section yang sama disurvey dalam beberapa waktu.

Menurut Widarjono (2009) analisis regresi linier berganda dengan data panel memberikan beberapa keunggulan dibandingkan dengan pendekatan standar cross section dan time series, antara lain seperti data panel yang merupakan gabungan dua data time series dan cross section mampu menyediakan data yang lebih banyak sehingga akan menghasilkan degree of freedom yang lebih besar. Lalu menggabungkan informasi dari data time series dan cross section dapat mengatasi masalah yang timbul ketika ada masalah penghilangan variabel.

Untuk menjawab permasalahan yang pertama yaitu untuk mengetahui pengaruh pertumbuhan ekonomi terhadap belanja daerah di 5 kabupaten induk yang ada di provinsi jambi, model yang digunakan adalah sebagai berikut :

$$
\mathrm{BD}_{\mathrm{it}}=\boldsymbol{\beta}_{0}+\boldsymbol{\beta}_{1} \mathrm{PE}_{\mathrm{it}}+\mu_{\mathrm{it}}
$$

\section{Dimana :}

$\mathrm{BD}_{\mathrm{it}} \quad$ : Belanja daerah di 5 Kabupaten induk di Provinsi

$\beta_{0} \quad$ : Konstanta

$\beta_{1} \quad$ : Koefisien regresi

$\mathrm{PE}_{\mathrm{it}} \quad$ : Pertumbuhan ekonomi di 5 Kabupaten induk di Provinsi Jambi

$\mu_{\mathrm{i}} \quad$ : Cross section i

: Time series

$: 1,2,3, \ldots .10$ (data cross section 5 Kabupaten induk di Provinsi Jambi)

Untuk menjawab pertanyaan yang kedua yaitu untuk mengetahui pengaruh jumlah penduduk terhadap belanja daerah di 5 kabupaten induk yang ada di provinsi jambi, model yang digunakan adalah sebagai berikut :

$$
\mathrm{BD}_{\mathrm{it}}=\boldsymbol{\beta}_{\mathbf{0}}+\boldsymbol{\beta}_{1} \mathrm{JP}_{\mathrm{it}}+\boldsymbol{\mu}_{\mathrm{it}}
$$

\section{Dimana :}

$\mathrm{BD}_{\text {it }} \quad$ : Belanja daerah di 5 Kabupaten induk di Provinsi

$\beta_{0} \quad$ : Konstanta

$\beta_{1} \quad$ : Koefisien regresi

$\mathrm{JP}_{\text {it }} \quad$ : Jumlah penduduk di 5 Kabupaten induk di Provinsi Jambi

$\mu_{\mathrm{i}} \quad$ : Cross section $\mathrm{i}$

$\begin{array}{ll}\mathrm{t} & : \text { Time series } \\ \mathrm{i} & : 1,2,3, \ldots .10 \text { (data cross section } 5 \text { kabupaten induk di Provinsi Jambi) }\end{array}$

Untuk menjawab pertanyaan yang ketiga yaitu untuk mengetahui pengaruh pendapatan asli daerah terhadap belanja daerah di 5 kabupaten induk yang ada di provinsi jambi, model yang digunakan adalah sebagai berikut : 
Dimana :

$$
\mathbf{B D}_{\mathrm{it}}=\boldsymbol{\beta}_{\mathbf{0}}+\boldsymbol{\beta}_{1} \mathbf{P A D}_{\mathrm{it}}+\mu_{\mathrm{it}}
$$

$\mathrm{BD}_{\text {it }} \quad$ : Belanja daerah di 5 Kabupaten induk di Provinsi

$\beta_{0} \quad$ : Konstanta

$\beta_{1} \quad$ : Koefisien regresi

PAD $_{\text {it }}$ : Pendapatan asli daerah di 5 Kabupaten induk di Provinsi Jambi

$\mu_{\mathrm{i}} \quad$ : Cross Section i

$\mathrm{t} \quad$ : Time Series

i $\quad: 1,2,3, \ldots .10$ (data cross section 5 kabupaten induk di Provinsi Jambi)

Untuk mengetahui pengaruh pertumbuhan ekonomi, jumlah penduduk, dan PAD, terhadap belanja daerah di 5 kabupaten induk yang ada di Provinsi Jambi. Model yang digunakan adalah sebagai berikut :

Dimana :

$$
\mathrm{BD}_{\mathrm{it}}=\boldsymbol{\beta}_{0}+\beta_{1} \mathbf{P E}_{\mathrm{it}}+\boldsymbol{\beta}_{2} \mathrm{JP}_{\mathrm{it}}+\boldsymbol{\beta}_{3} \mathbf{P A D}_{\mathrm{it}}+\mu_{\mathrm{it}}
$$

BD $_{\text {it }} \quad$ : Belanja daerah di 5 Kabupaten induk di Provinsi

$\mathrm{PE}_{\mathrm{it}} \quad$ : Pertumbuhan ekonomi di 5 Kabupaten induk di Provinsi Jambi

$\mathrm{JP}_{\text {it }} \quad$ : Jumlah penduduk di 5 Kabupaten induk di Provinsi Jambi

$\mathrm{PAD}_{\text {it }} \quad$ : Pendapatan asli daerah di 5 Kabupaten induk di Provinsi Jambi

$\beta_{0} \quad$ : Konstanta

$\beta_{1}, \beta_{2} \beta_{3}$ : Koefisien regresi

$\mu_{\mathrm{i}} \quad$ : Cross section $\mathrm{i}$

$\mathrm{t} \quad$ : Time series

i $\quad: 1,2,3, \ldots .10$ (data cross section 5 Kabupaten induk di Provinsi Jambi

\section{HASIL DAN PEMBAHASAN}

Pengaruh pertumbuhan ekonomi terhadap belanja daerah pada Kabupaten Induk dalam Provinsi Jambi

Menganalisis data panel dapat dilakukan dengan menggunakan tiga metode, yaitu metode common effect (PLS), metode fixed effect (FEM), dan metode random effect (REM). Pendekatan PLS ini menggunakan metode OLS biasa. Metode ini merupakan metode paling sederhana. Dalam estimasi diasumsikan setiap unit individu memiliki intersep dan slope yang sama (tidak ada perbedaan pada dimensi kerat waktu). Untuk digunakan dalam mengestimasi data panel, maka akan dilakukan pengujian pemilihan model dengan menggunakan Uji Chow atau Likelihood tes ratio dan uji Hausman. Berikut ini akan ditampilkan hasil pengujian tersebut.

Tabel 1. Uji Chow untuk memilih antara model PLS dengan FEM

\begin{tabular}{lrrr}
\hline \hline Effects Test & Statistik & d.f. & Prob. \\
\hline \hline Cross-section F & 1.177842 & $(3,15)$ & 0.0013 \\
Cross-section Chi-square & 4.230622 & 3 & 0.0076 \\
\hline \hline
\end{tabular}

Sumber: Data diolah, 2019

Adapun hipotesis yang digunakan dalam pemilihan Uji Chow ini adalah Jika pvalue $<\alpha$, maka $H_{0}$ ditolak dan $H_{1}$ diterima, artinya model FEM lebih baik dibandingkan 
model PLS. Sedangkan jika p-value $>\alpha$, maka $H_{1}$ ditolak dan $H_{0}$ diterima, artinya model PLS lebih baik dibandingkan model FEM.

Berdasarkan output Eviews tersebut menunjukan bahwa baik F test maupun ChiSquare signifikan (Prob. 0.0013 dan 0.0076 lebih kecil dibandingkan alfa $=0.05 \%$ dengan signifikan 95 persen, sehingga model ini hipotesis Ho ditolak dan $\mathrm{H}_{1}$ diterima. Dengan demikian, dapat disimpulkan bahwa model FEM lebih baik dibandingkan model PLS.

Tabel 2. Uji Hausman untuk memilih antara model FEM dengan REM

\begin{tabular}{lccc}
\hline \hline Test Summary & Chi-Sq. Statistik & Chi-Sq. d.f. & Prob. \\
\hline \hline Cross-section random & 0.465582 & 1 & 0.4950 \\
\hline \hline
\end{tabular}

Sumber: Data diolah, 2019

Adapun hipotesis yang digunakan dalam pemilihan Uji Hausman ini adalah jika p-value $<\alpha$, maka $H_{0}$ ditolak dan $H_{1}$ diterima, artinya model REM lebih baik dibandingkan model FEM. Sedangkan jika p-value $>\alpha$, maka $H_{1}$ ditolak dan $H_{0}$ diterima, artinya model FEM lebih baik dibandingkan model REM.

Berdasarkan output Eviews tersebut menunjukan bahwa nilai statistik Chi-Square memiliki Prob lebih besar dibandingkan alfa 0.05 persen dengan signifikansi 95 persen maka $(0.4950>0.05 \%)$, sehingga hipotesis $\mathrm{H}_{1}$ ditolak dan $\mathrm{H}_{0}$ diterima. Dengan demikian dapat disimpulkan bahwa model FEM lebih baik dibandingkan REM. Dengan menggunakan model FEM di peroleh hasil regresi data panel dengan persamaan sebagai berikut:

Tabel 3. Hasil persamaan regresi data panel model FEM

\begin{tabular}{lllll}
\hline Variabel & Koefisien & Stand. Error & t-statistik & Prob. \\
\hline C & 9.233757 & 1.504319 & 6.138164 & 0.0000 \\
PE & $-2.29 \mathrm{E}-12$ & $1.40 \mathrm{E}-12$ & -1.638219 & 0.1150 \\
R-Squared & 0.104492 & & & \\
F-Statistik & 2.683760 & & & \\
Prob-F & 0.114986 & & & \\
\hline
\end{tabular}

Sumber: Data diolah, 2019

\section{$\mathrm{BD}=9.233757-0.000229 \mathrm{PE}$}

Berdasarkan Tabel 3 hasil estimasi terhadap fixed effect model adalah jika terjadi perubahan antara variabel pertumbuhan ekonomi baik antar provinsi maupun antar waktu, maka nilai konstanta sebesar 9.233757 Hal ini berarti jika pertumbuhan ekonomi tetap (konstan), maka belanja daerah adalah sebesar 9.233757 rupiah. Nilai koefisien pertumbuhan ekonomi sebesar -0.000229. Hal ini diartikan jika pertumbuhan ekonomi meningkat satu persen maka belanja daerah akan menurun sebesar 0.000229 rupiah.

Dari hasil pengujian diperoleh koefisien determinasi $\left(\mathrm{R}^{2}\right)$ sebesar 0.104492 Artinya sebesar 10.44 persen belanja daerah di Provinsi Jambi periode 2012 - 2016 jelaskan oleh variabel pertumbuhan ekonomi, sedangkan sisanya 89.56 persen dijelaskan variabel lainnya yang tidak dimasukkan didalam penelitian ini.

\section{Uji F statistik}

Pada output eviews dapat dilihat bahwa p-value lebih besar dibandingkan $\alpha=0.05$ $\%(0.114986>0,05)$ artinya Ho ditolak dan Ha diterima maka variabel pertumbuhan 
ekonomi secara bersama-sama tidak pengaruh yang signifikan terhadap belanja daerah pada 5 kabupaten induk di Provinsi Jambi tahun 2012 - 2016.

\section{Uji t statistik}

Uji t digunakan untuk menguji pengaruh individu dari variabel-variabel bebas terhadap variabel terikat. Pengujian t-statistik dilakukan dengan membandingkan antara p-value atau Prob (t-statistik) dengan $\alpha=0.05 \%$ dengan tingkat signifikansi 95 persen. Jika $p$ value lebih kecil dibandingkan $\alpha$, maka pengaruh variabel bebas terhadap variabel terikat adalah signifikan. Sebaliknya apaabila p-value lebih besar dibandingkan dengan $\alpha$ maka pengaruh variabel bebas terhadap variabel terikat adalah tidak signifikan. Berdasarkan output Eviews diperolah hasil sebagai berikut :

Tabel 4. Nilai $t$ statistik pada metode FEM

\begin{tabular}{lccl}
\hline Variabel & $\begin{array}{c}\text { Prob (t-statistik) } \\
(\mathbf{p} \text {-value) }\end{array}$ & $\begin{array}{c}\text { Tingkat Signifikansi } \\
(\boldsymbol{\alpha})\end{array}$ & Keterangan \\
\hline $\begin{array}{l}\text { Pertumbuhan } \\
\text { ekonomi }\end{array}$ & 0.1150 & 0.05 & Tidak signifikan \\
\hline
\end{tabular}

Sumber: Data diolah, 2019

Berdasarkan Tabel 4 diatas dapat dijelaskan bahwa variabel bebas yang memiliki p-value lebih besar dibandingkan dengan alfa 0.05 persen yang artinya variabel tersebut tidak berpengaruh signifikan terhadap variabel terikat. Variabel pertumbuhan ekonomi tidak pengaruh signifikan terhadap belanja daerah pada 5 kabupaten induk di Provinsi Jambi tahun 2012 - 2016 karena prob t-statistik sebesar $0.1150>0.05$ alfa dengan signifikansi 95 persen. Dari hasil estimasi dengan menggunakan Fixed Effect Model dapat dijelaskan bahwa masing - masing Provinsi memiliki nilai intersep yang berbeda beda. Individual effect dapat dilihat dari tabel berikut ini :

Tabel 5. Koefisien intersep Kabupaten/Kota hasil estimasi model

\begin{tabular}{lccc}
\hline \hline Kabupaten/Kota & Konstanta & Fixed Effect Model & Individual Effect \\
\hline \hline & & & \\
Bungo & 9.233757 & 0.036321 & 9.270078 \\
Merangin & 9.233757 & 0.046241 & 9.279998 \\
Kerinci & 9.233757 & 0.017823 & 9.25158 \\
Batanghari & 9.233757 & -0.053990 & 9.179767 \\
Tanjab Barat & 9.233757 & -0.010074 & 9.223683 \\
\hline \hline
\end{tabular}

Sumber : Data diolah, 2019

Berdasarkan Tabel 5 tersebut dapat dilihat bahwa nilai intersep dengan menggunakan hasil estimasi metode FEM dapat dijelaskan bahwa jika terjadi perubahan pertumbuhan ekonomi baik antar daerah maupun antar waktu maka Kabupaten Bungo akan mendapatkan pengaruh individual effect terhadap terhadap belanja daerah pada 5 kabupaten induk di Provinsi Jambi tahun 2012 - 2016 sebesar 9.270078 rupiah. Jika terjadi perubahan pertumbuhan ekonomi baik antar kabupaten maupun antar waktu, maka Kabupaten Merangin akan mendapatkan pengaruh individual effect terhadap terhadap 
belanja daerah pada 5 kabupaten induk di Provinsi Jambi tahun 2012 - 2016 sebesar 9.279998 rupiah.

Apabila terjadi perubahan pertumbuhan ekonomi baik antar kabupaten maupun antar waktu, maka Kabupaten Kerinci akan mendapatkan pengaruh individual effect terhadap terhadap belanja daerah pada 5 kabupaten induk di Provinsi Jambi tahun 2012 2016 sebesar 9.25158 rupiah. Kabupaten Batanghari jika terjadi perubahan pertumbuhan ekonomi baik antar kabupaten maupun antar waktu, maka akan mendapatkan pengaruh individual effect terhadap terhadap belanja daerah pada 5 kabupaten induk di Provinsi Jambi tahun 2012 - 2016 sebesar 9.179767 rupiah. Jika Tanjung Jabung Barat jika terjadi perubahan pertumbuhan ekonomi baik antar kabupaten maupun antar waktu, maka Kabupaten Tanjung Jabung Barat akan mendapatkan pengaruh individual effect terhadap terhadap belanja daerah pada 5 kabupaten induk di Provinsi Jambi tahun 2012 - 2016 sebesar 9.223683 rupiah.

\section{Pengaruh jumlah penduduk terhadap belanja daerah pada Kabupaten Induk dalam Provinsi Jambi}

Bagian ini akan menjelaskan pengaruh jumlah penduduk terhadap belanja daerah pada 5 kabupaten induk di Provinsi Jambi yang menggunakan perhitungan regresi sederhana data panel yang menggabungkan antara data time series dan data cross section. Data time series yang digunakan adalah data tahunan yaitu tahun 2012-2016 dan cross section adalah objek data yaitu meliputi 5 kabupaten induk (Kabupaten Bungo, Merangin, Kerinci, Batanghari dan Tanjung Jabung Barat) di Provinsi Jambi. Guna mengestimasi data panel, maka akan dilakukan pengujian pemilihan model dengan menggunakan Uji Chow dan Uji Hausman. Berikut ini akan ditampilkan hasil pengujian tersebut.

Tabel 6. Uji Chow untuk memilih antara model PLS dengan FEM

\begin{tabular}{lrrr}
\hline Effects Test & Statistik & d.f. & Prob. \\
\hline Cross-section F & 4.646307 & $(3,15)$ & 0.0173 \\
Cross-section Chi-square & 13.142744 & 3 & 0.0043 \\
\hline
\end{tabular}

Sumber: Data diolah, 2019

Adapun hipotesis yang digunakan dalam pemilihan Uji Chow ini adalah jika pvalue $<\alpha$, maka $H_{0}$ ditolak dan $H_{1}$ diterima, artinya model FEM lebih baik dibandingkan model PLS. Jika p-value $>\alpha$, maka $H_{1}$ ditolak dan $H_{0}$ diterima, artinya model PLS lebih baik dibandingkan model FEM.

Berdasarkan output Eviews tersebut menunjukan bahwa baik $\mathrm{F}$ test maupun ChiSquare signifikan (Prob. 0.00173 dan 0.0043 lebih kecil dibandingkan alfa $=0.05 \%$ dengan signifikan 95 persen, sehingga model ini hipotesis Ho ditolak dan H1 diterima. Dengan demikian, dapat disimpulkan bahwa model FEM lebih baik dibandingkan model PLS. Selanjutnya akan dilakukan Uji Hausman untuk memilih model mana yang paling baik antara FEM dengan REM.

Tabel 7. Uji Hausman untuk memilih antara model FEM dengan REM

\begin{tabular}{lrcc}
\hline \hline Test Summary & Chi-Sq. Statistik & Chi-Sq. d.f. & Prob. \\
\hline \hline Cross-section random & 12.327231 & 1 & 0.1144 \\
\hline \hline
\end{tabular}

Sumber: Data diolah, 2019 
Adapun hipotesis yang digunakan dalam pemilihan Uji Hausman ini adalah jika p-value $<\alpha$, maka $H_{0}$ ditolak dan $H_{1}$ diterima, artinya model REM lebih baik dibandingkan model FEM. Jika p-value $>\alpha$, maka $H_{1}$ ditolak dan $H_{0}$ diterima, artinya model FEM lebih baik dibandingkan model REM. Berdasarkan output Eviews tersebut menunjukan bahwa nilai statistik Chi-Square memiliki Prob lebih besar dibandingkan alfa 0.05 persen dengan signifikansi 95 persen maka $(0.1144>0.05 \%)$, sehingga hipotesis $\mathrm{H}_{1}$ ditolak dan $\mathrm{H}_{0}$ diterima. Dengan demikian dapat disimpulkan bahwa model FEM lebih baik dibandingkan REM. Dengan menggunakan model FEM di peroleh hasil regresi data panel dengan persamaan sebagai berikut:

Tabel 8. Hasil persamaan regresi data panel model FEM

\begin{tabular}{llccc}
\hline Variabel & Koefisien & Stand. Error & t-statistik & Prob. \\
\hline C & $-3.49 \mathrm{E}+12$ & $1.15 \mathrm{E}+12$ & -3.038678 & 0.0083 \\
JP & 15085502 & 3862562 & 3.905569 & 0.0014 \\
R-Squared & 0.600207 & & & \\
F-Statistik & 5.629849 Prob-F & 0.005679 & \\
\hline
\end{tabular}

Sumber : Data diolah, 2019

$$
\mathrm{BD}=-\mathbf{0 . 0 0 0 3 4 9}+\mathbf{1 5 0 8 5 5 0 2} \mathrm{JP}
$$

Berdasarkan Tabel 8 hasil estimasi terhadap fixed effect model adalah jika terjadi perubahan antara variabel jumlah penduduk baik antar provinsi maupun antar waktu, nilai konstanta sebesar -0.000349 Hal ini berarti jika jumlah penduduk tetap (konstan), maka belanja daerah sebesar -0.000349 rupiah. Nilai koefisien jumlah penduduk sebesar 15085502. Hal ini diartikan jika penduduk meningkat satu jiwa maka belanja daerah akan meningkat sebesar 15085502 rupiah.

Dari hasil pengujian diperoleh koefisien determinasi $\left(\mathrm{R}^{2}\right)$ sebesar 0.600207 Artinya sebesar 60.02 persen belanja daerah di Provinsi Jambi periode 2012 - 2016 jelaskan oleh variabel jumlah penduduk, sedangkan sisanya 39.98 persen dijelaskan variabel lainnya yang tidak dimasukkan didalam penelitian ini.

\section{Uji F statistik}

Pada output eviews dapat dilihat bahwa p-value lebih kecil dibandingkan $\alpha=0.05$ $\%(0.005679<0,05)$ atau F tabel $5.629849<$ F Statistik 2.03 artinya Ho ditolak dan Ha diterima maka variabel jumlah penduduk secara bersama-sama pengaruh yang signifikan terhadap belanja daerah pada 5 kabupaten induk di Provinsi Jambi tahun 2012 - 2016.

\section{Uji t Statistik}

Uji t digunakan untuk menguji pengaruh individu dari variabel-variabel bebas terhadap variabel terikat. Pengujian t-statistik dilakukan dengan membandingkan antara p-value atau Prob (t-statistik) dengan $\alpha=0.05 \%$ dengan tingkat signifikansi 95 persen. Jika $p$ value lebih kecil dibandingkan $\alpha$, maka pengaruh variabel bebas terhadap variabel terikat adalah signifikan. Sebaliknya apabila p-value lebih besar dibandingkan dengan $\alpha$ maka pengaruh variabel bebas terhadap variabel terikat adalah tidak signifikan. Berdasarkan output Eviews diperolah hasil sebagai berikut : 
Tabel 9. Nilai t statistik pada metode FEM

\begin{tabular}{lccc}
\hline Variabel & $\begin{array}{c}\text { Prob (t-statistik) } \\
\text { (p-value) }\end{array}$ & $\begin{array}{c}\text { Tingkat Signifikansi } \\
(\boldsymbol{\alpha})\end{array}$ & Keterangan \\
\hline Jumlah Penduduk & 0.0014 & 0.05 & Signifikan \\
\hline
\end{tabular}

Sumber: Data diolah, 2019

Berdasarkan Tabel 9 diatas dapat dijelaskan bahwa variabel bebas yang memiliki p-value lebih kecil dibandingkan dengan alfa 0.05 persen yang artinya variabel tersebut berpengaruh signifikan terhadap variabel terikat. Variabel jumlah penduduk pengaruh signifikan terhadap belanja daerah pada 5 kabupaten induk di Provinsi Jambi tahun 2012 - 2016 karena prob t-statistik sebesar $0.0014<0.05$ alfa dengan signifikansi 95 persen. Dari hasil estimasi dengan menggunakan Fixed Effect Model dapat dijelaskan bahwa masing - masing Provinsi memiliki nilai intersep yang berbeda - beda. Individual effect dapat dilihat dari tabel berikut ini:

Tabel 10. Koefisien intersep Kabupaten/Kota hasil estimasi model

\begin{tabular}{lccc} 
Kabupaten/Kota & Konstanta & Fixed Effect Model & Individual Effect \\
\hline Bungo & 0.000349 & -0.0000475 & 0.0003015 \\
Merangin & 0.000349 & -0.0000485 & 0.0003005 \\
Kerinci & 0.000349 & -0.0000897 & 0.0002593 \\
Batanghari & 0.000349 & -0.0000823 & 0.0004313 \\
Tanjab Barat & 0.000349 & -0.0000560 & 0.000405 \\
\hline
\end{tabular}

Sumber: Data diolah, 2019

Berdasarkan Tabel 10 tersebut dapat dilihat bahwa nilai intersep dengan menggunakan hasil estimasi metode FEM dapat dijelaskan bahwa jika terjadi perubahan jumlah penduduk baik antar daerah maupun antar waktu maka Kabupaten Bungo akan mendapatkan pengaruh individual effect terhadap belanja daerah pada 5 kabupaten induk di Provinsi Jambi tahun 2012 - 2016 sebesar 0.0003015 rupiah. Jika Kabupaten Merangin terjadi perubahan jumlah penduduk baik antar kabupaten maupun antar waktu, maka akan mendapatkan pengaruh individual effect terhadap terhadap belanja daerah pada 5 kabupaten induk di Provinsi Jambi tahun 2012 - 2016 sebesar 0.0003005 rupiah. Apabila Kabupaten Kerinci mengalami perubahan jumlah penduduk baik antar kabupaten maupun antar waktu, maka akan mendapatkan pengaruh individual effect terhadap terhadap belanja daerah pada 5 kabupaten induk di Provinsi Jambi tahun 2012 - 2016 sebesar 0.0002593 rupiah.

Kabupaten Batanghari jika terjadi perubahan jumlah penduduk baik antar kabupaten maupun antar waktu, maka akan mendapatkan pengaruh individual effect terhadap terhadap belanja daerah pada 5 kabupaten induk di Provinsi Jambi tahun 2012 2016 sebesar 0.0004313 rupiah. Jika terjadi perubahan jumlah penduduk baik antar kabupaten maupun antar waktu, maka Kabupaten Tanjung Jabung Barat akan mendapatkan pengaruh individual effect terhadap terhadap belanja daerah pada 5 kabupaten induk di Provinsi Jambi tahun 2012 - 2016 sebesar 0.000405 rupiah. 


\section{Pengaruh pendapatan asli daerah terhadap belanja daerah pada Kabupaten Induk dalam Provinsi Jambi}

Bagian ini akan menjelaskan pengaruh pendapatan asli daerah terhadap belanja daerah pada 5 kabupaten induk di Provinsi Jambi yang menggunakan perhitungan regresi sederhana data panel yang menggabungkan antara data time series dan data cross section. Data time series yang digunakan adalah data tahunan yaitu tahun 2012-2016 dan cross section adalah objek data yaitu meliputi 5 kabupaten induk (Kabupaten Bungo, Merangin, Kerinci, Batanghari dan Tanjung Jabung Barat) di Provinsi Jambi. Guna mengestimasi data panel, maka akan dilakukan pengujian pemilihan model dengan menggunakan Uji Chow dan Uji Hausman.

Adapun hipotesis yang digunakan dalam pemilihan Uji Chow ini adalah jika pvalue $<\alpha$, maka $H_{0}$ ditolak dan $H_{1}$ diterima, artinya model FEM lebih baik dibandingkan model PLS. Jika p-value $>\alpha$, maka $H_{1}$ ditolak dan $H_{0}$ diterima, artinya model PLS lebih baik dibandingkan model FEM. Berikut ini akan ditampilkan hasil pengujian tersebut

Tabel 11. Uji Chow untuk memilih antara model PLS dengan FEM

\begin{tabular}{lcrr}
\hline Effects Test & Statistik & d.f. & Prob. \\
\hline Cross-section F & 0.832051 & $(3,15)$ & 0.0068 \\
Cross-section Chi-square & 3.078618 & 3 & 0.0097
\end{tabular}

Sumber: Data diolah, 2019

Berdasarkan output Eviews tersebut menunjukan bahwa baik F test maupun ChiSquare signifikan (Prob. 0.00069 dan 0.00097 lebih kecil dibandingkan alfa $=0.05 \%$ dengan signifikan 95 persen, sehingga model ini hipotesis Ho ditolak dan H1 diterima. Dengan demikian, dapat disimpulkan bahwa model FEM lebih baik dibandingkan model PLS.

Tabel 12. Uji Hausman untuk memilih antara model FEM dengan REM

Test Summary Chi-Sq. Statistik Chi-Sq. d.f. Prob.

$\begin{array}{llll}\text { Cross-section random } & 0.605605 & 1 & 0.4364\end{array}$

Sumber: Data diolah, 2019

Adapun hipotesis yang digunakan dalam pemilihan Uji Hausman ini adalah jika p-value $<\alpha$, maka $H_{0}$ ditolak dan $H_{1}$ diterima, artinya model REM lebih baik dibandingkan model FEM. Jika p-value $>\alpha$, maka $H_{1}$ ditolak dan $H_{0}$ diterima, artinya model FEM lebih baik dibandingkan model REM.

Berdasarkan output Eviews tersebut menunjukan bahwa nilai statistik Chi-Square memiliki Prob lebih besar dibandingkan alfa 0.05 persen dengan signifikansi 95 persen maka $(0.4364>0.05 \%)$, sehingga hipotesis $\mathrm{H}_{1}$ ditolak dan $\mathrm{H}_{0}$ diterima. Dengan demikian dapat disimpulkan bahwa model FEM lebih baik dibandingkan REM. Dengan menggunakan model FEM di peroleh hasil regresi data panel dengan persamaan pada Tabel 13. Berdasarkan Tabel 13 hasil estimasi terhadap fixed effect model adalah jika terjadi perubahan antara variabel pendapatan asli daerah baik antar provinsi maupun antar waktu, maka nilai konstanta sebesar 11.86459. Hal ini berarti jika pendapatan asli daerah 
tetap (konstan), maka belanja daerah adalah sebesar 11.86459 rupiah. Nilai koefisien pendapatan asli daerah sebesar 0.000195. Hal ini diartikan jika pendapatan asli daerah meningkat satu rupiah maka belanja daerah akan meningkat sebesar 0.000195 rupiah.

Tabel 13. Hasil persamaan regresi data panel model FEM

\begin{tabular}{llccc}
\hline Variabel & Koefisien & Stand. Error & t-statistik & Prob. \\
\hline C & 11.86459 & 0.048992 & 242.1752 & 0.0000 \\
PAD & $1.95 \mathrm{E}-12$ & $7.20 \mathrm{E}-13$ & 2.703402 & 0.0163 \\
R-Squared & 0.465335 & & & \\
F-Statistik & 3.263739 & & & \\
Prob-F & 0.041007 & & & \\
\hline
\end{tabular}

Sumber: Data diolah, 2019

\section{$\mathrm{BD}=11.86459+0.000195$ PAD}

Dari hasil pengujian diperoleh koefisien determinasi $\left(\mathrm{R}^{2}\right)$ sebesar 0.465335 Artinya sebesar 46.53 persen belanja daerah di Provinsi Jambi periode 2012 - 2016 jelaskan oleh variabel pendapatan asli daerah, sedangkan sisanya 53.47 persen dijelaskan variabel lainnya yang tidak dimasukkan didalam penelitian ini.

\section{Uji F statistik}

Pada output eviews dapat dilihat bahwa p-value lebih kecil dibandingkan $\alpha=0.05$ $\%(0.041007<0,05)$ atau F tabel $3.263739<$ F Statistik 2.03 artinya Ho ditolak dan Ha diterima maka variabel PAD secara bersama-sama pengaruh yang signifikan terhadap belanja daerah pada 5 kabupaten induk di Provinsi Jambi tahun 2012 - 2016.

\section{Uji t statistik}

Uji t digunakan untuk menguji pengaruh individu dari variabel-variabel bebas terhadap variabel terikat. Pengujian t-statistik dilakukan dengan membandingkan antara p-value atau Prob (t-statistik) dengan $\alpha=0.05 \%$ dengan tingkat signifikansi 95 persen. Jika $p$ value lebih kecil dibandingkan $\alpha$, maka pengaruh variabel bebas terhadap variabel terikat adalah signifikan. Sebaliknya apaabila p-value lebih besar dibandingkan dengan $\alpha$ maka pengaruh variabel bebas terhadap variabel terikat adalah tidak signifikan. Berdasarkan output Eviews diperoleh hasil sebagai berikut :

Tabel 14. Nilai $t$ statistik pada metode FEM

\begin{tabular}{lccc}
\hline Variabel & $\begin{array}{c}\text { Prob (t-statistik) } \\
(\mathbf{p} \text {-value })\end{array}$ & $\begin{array}{c}\text { Tingkat Signifikans } \\
(\boldsymbol{\alpha})\end{array}$ & Keterangan \\
\hline PAD &. .0 .0163 & 0.05 & Signifikan \\
\hline
\end{tabular}

Sumber : Data diolah, 2019

Variabel PAD pengaruh signifikan terhadap belanja daerah pada 5 kabupaten induk di Provinsi Jambi tahun 2012 - 2016 karena prob t-statistik sebesar $0.0163<0.05$ alfa dengan signifikansi 95 persen. Dari hasil estimasi dengan mIenggunakan Fixed Effect Model dapat dijelaskan bahwa masing - masing Provinsi memiliki nilai intersep yang berbeda - beda. Individual effect dapat dilihat dari tabel berikut ini : 
Tabel 15. Koefisien intersep Kabupaten/Kota hasil estimasi model

\begin{tabular}{lccc}
\hline Kabupaten/Kota & Konstanta & $\begin{array}{c}\text { Fixed Effect } \\
\text { Model }\end{array}$ & Individual Effect \\
\hline Bungo & 11.86459 & 0.015077 & 11.87967 \\
Merangin & 11.86459 & 0.017087 & 11.88168 \\
Kerinci & 11.86459 & 0.026377 & 11.89097 \\
Batanghari & 11.86459 & -0.037892 & 11.82669 \\
Tanjab Barat & 11.86459 & -0.005573 & 11.85902 \\
\hline
\end{tabular}

Sumber : Data diolah 2019

Berdasarkan Tabel 15 tersebut dapat dilihat bahwa jika terjadi perubahan PAD baik antar daerah maupun antar waktu maka Kabupaten Bungo akan mendapatkan pengaruh individual effect terhadap terhadap belanja daerah pada 5 kabupaten induk di Provinsi Jambi tahun 2012 - 2016 sebesar 11.87967 rupiah. Jika Kabupaten Merangin terjadi perubahan PAD baik antar kabupaten maupun antar waktu, maka Kabupaten Merangin akan mendapatkan pengaruh individual effect terhadap terhadap belanja daerah pada 5 kabupaten induk di Provinsi Jambi tahun 2012 - 2016 sebesar 11.88168 rupiah. Apabila Kabupaten Kerinci mengalami perubahan PAD baik antar kabupaten maupun antar waktu, maka akan mendapatkan pengaruh individual effect terhadap terhadap belanja daerah pada 5 kabupaten induk di Provinsi Jambi tahun 2012 - 2016 sebesar 11.89097 rupiah.

Kabupaten Batanghari jika terjadi perubahan PAD baik antar kabupaten maupun antar waktu, maka akan mendapatkan pengaruh individual effect terhadap terhadap belanja daerah pada 5 kabupaten induk di Provinsi Jambi tahun 2012 - 2016 sebesar 11.82669 rupiah. apabila Kabupaten Tanjung Jabung Barat mengalami perubahan PAD baik antar kabupaten maupun antar waktu, maka akan mendapatkan pengaruh individual effect terhadap terhadap belanja daerah pada 5 kabupaten induk di Provinsi Jambi tahun 2012 - 2016 sebesar 11.85902 rupiah.

\section{Pengaruh pertumbuhan ekonomi, jumlah penduduk, dan pad terhadap belanja daerah pada 5 kabupaten induk di Provinsi Jambi}

Bagian ini akan membahas bagaimana pengaruh pertumbuhan ekonomi, jumlah penduduk, dan pad secara bersama-sama terhadap belanja daerah di Kabupaten induk yang ada di Provinsi Jambi dengan metode regresi berganda dengan menggunakan data panel. Guna menentukan model yang paling tepat, akan dilakukan pengujian pemilihan model dengan menggunakan Uji Chow dan Uji Hausman. Berikut ini akan ditampilkan hasil pengujian tersebut.

Tabel 16. Uji Chow untuk memilih antara model PLS dengan FEM

\begin{tabular}{llrr}
\hline Effects Test & Statistik & d.f. & Prob. \\
\hline Cross-section F & 2.577075 & $(3,13)$ & 0.0986 \\
Cross-section Chi-square & 9.333833 & 3 & 0.0252 \\
\hline
\end{tabular}

Sumber: Data diolah, 2019

Adapun hipotesis yang digunakan dalam pemilihan Uji Chow ini adalah jika pvalue $<\alpha$, maka $H_{0}$ ditolak dan $H_{1}$ diterima, artinya model FEM lebih baik dibandingkan 
model PLS. Jika p-value $>\alpha$, maka $H_{1}$ ditolak dan $H_{0}$ diterima, artinya model PLS lebih baik dibandingkan model FEM.

Berdasarkan output Eviews tersebut menunjukan bahwa baik F test maupun ChiSquare signifikan (Prob. 0.0986 dan 0.0252 lebih besar dibandingkan alfa $=0.05 \%$ dengan signifikan 95 persen, sehingga model ini hipotesis Ho diterima dan H1 ditolak. Dengan demikian, dapat disimpulkan bahwa model PLS lebih baik dibandingkan model FEM.

Tabel 17. Uji Hausman untuk memilih antara model FEM dengan REM

\begin{tabular}{lrrr}
\hline Test Summary & Chi-Sq. Statistik & Chi-Sq. d.f. & Prob. \\
\hline \hline Cross-section random & 7.731225 & 3 & 0.0419 \\
\hline
\end{tabular}

Sumber: Data diolah, 2019

Adapun hipotesis yang digunakan dalam pemilihan Uji Hausman ini adalah jika p-value $<\alpha$, maka $H_{0}$ ditolak dan $H_{1}$ diterima, artinya model REM lebih baik dibandingkan model FEM. Jika p-value $>\alpha$, maka $H_{1}$ ditolak dan $H_{0}$ diterima, artinya model FEM lebih baik dibandingkan model REM.

Berdasarkan output Eviews tersebut menunjukan bahwa nilai statistik Chi-Square memiliki Prob lebih kecil dibandingkan alfa 0.05 persen dengan signifikansi 95 persen maka $(0.0419<0.05 \%)$, sehingga hipotesis Ho ditolak dan H1 diterima. Dengan demikian dapat disimpulkan bahwa model REM lebih baik dibandingkan FEM.

Dengan menggunakan model REM di peroleh hasil regresi data panel dengan persamaan sebagai berikut:

Tabel 18. Hasil persamaan regresi data panel model REM

\begin{tabular}{llcll}
\hline Variabel & Koefisien & Stand. Error & t-statistik & Prob. \\
\hline C & $4.15 \mathrm{E}+11$ & $3.09 \mathrm{E}+11$ & 1.345205 & 0.1973 \\
PE & $-4.64 \mathrm{E}+09$ & $2.41 \mathrm{E}+10$ & -0.192925 & 0.8494 \\
JP & 1191467 & 677153.5 & 1.759523 & 0.0976 \\
PAD & 3.998844 & 1.356863 & 2.947125 & 0.0095 \\
R-Squared & 0.461026 & & & \\
F-Statistik & 4.562009 & & & \\
Prob-F & 0.017137 & & & \\
\hline
\end{tabular}

Sumber: Data diolah, 2019

$$
\mathrm{BD}=0.000415-0.000464 \mathrm{PE}+1191467 \mathrm{JP}+3.998844 \mathrm{PAD}
$$

Berdasarkan hasil estimasi terhadap random effect model adalah jika terjadi perubahan antara variabel pertumbuhan ekonomi, penduduk, dan pendapatan asli daerah baik antar provinsi maupun antar waktu, maka nilai konstanta sebesar 0.000415. Hal ini berarti jika pertumbuhan ekonomi, jumlah penduduk, dan PAD tetap (konstan), maka belanja daerah adalah sebesar 0.000415 rupiah.

Nilai koefisien pertumbuhan ekonomi sebesar -0.000464. Hal ini diartikan jika pertumbuhan ekonomi meningkat satu persen maka belanja daerah akan menurun sebesar -0.000464 rupiah. Nilai koefisien penduduk sebesar 1191467 Hal ini diartikan jika penduduk meningkat satu jiwa maka belanja daerah akan meningkat sebesar 1191467 
rupiah, Nilai koefisien pendapatan asli daerah sebesar 3.998844. Hal ini diartikan jika pendapatan asli daerah meningkat satu rupiah maka belanja daerah akan meningkat sebesar 3.998844 rupiah.

Dari hasil pengujian diperoleh koefisien determinasi $\left(\mathrm{R}^{2}\right)$ sebesar 0.461026 . Artinya sebesar 46.10 persen belanja daerah di Provinsi Jambi periode 2012 - 2016 jelaskan oleh variabel pertumbuhan ekonomi, jumlah penduduk, dan PAD, sedangkan sisanya 53.90 persen dijelaskan variabel lainnya yang tidak dimasukkan didalam penelitian ini.

\section{Uji F statistik}

Pada output eviews dapat dilihat bahwa p-value lebih kecil dibandingkan $\alpha=0.05$ $\%(0.017137<0,05)$ atau F tabel $4.562009>$ F Statistik 2.03 artinya Ho ditolak dan Ha diterima maka variabel pertumbuhan ekonomi, jumlah penduduk, dan PAD secara bersama-sama berpengaruh signifikan terhadap belanja daerah pada 5 kabupaten induk di Provinsi Jambi tahun 2012 - 2016.

\section{Uji t statistik}

Uji t digunakan untuk menguji pengaruh individu dari variabel-variabel bebas terhadap variabel terikat. Pengujian t-statistik dilakukan dengan membandingkan antara p-value atau Prob (t-statistik) dengan $\alpha=0.05 \%$ dengan tingkat signifikansi 95 persen. Jika $\mathrm{p}$ value lebih kecil dibandingkan $\alpha$, maka pengaruh variabel bebas terhadap variabel terikat adalah signifikan. Sebaliknya apaabila p-value lebih besar dibandingkan dengan $\alpha$ maka pengaruh variabel bebas terhadap variabel terikat adalah tidak signifikan. Berdasarkan output Eviews diperolah hasil sebagai berikut :

Tabel 19. Nilai t statistik pada metode REM

\begin{tabular}{llll}
\hline Variabel & Prob (t-statistik) & $\begin{array}{c}\text { Tingkat Signifikansi } \\
(\mathbf{p}-\mathbf{v a l u e})\end{array}$ & $\begin{array}{c}\text { Keterangan } \\
(\boldsymbol{\alpha})\end{array}$ \\
\hline PE & 0.8494 & 0.05 & Tidak Signifikan \\
JP & 0.0976 & 0.05 & Tidak Signifikan \\
PAD & 0.0095 & 0.05 & Signifikan \\
\hline
\end{tabular}

Sumber: Data diolah, 2019

Berdasarkan Tabel 19 dapat dijelaskan bahwa variabel bebas yang memiliki pvalue lebih kecil dibandingkan dengan alfa 0.05 persen yang artinya variabel tersebut berpengaruh signifikan terhadap variabel terikat. Variabel pertumbuhan ekonomi tidak berpengaruh signifikan terhadap belanja daerah pada 5 kabupaten induk di Provinsi Jambi tahun 2012 - 2016 karena prob t-statistik sebesar $0.8494>0.05$ alfa dengan signifikansi 95 persen. Variabel penduduk tidak berpengaruh signifikan terhadap belanja daerah pada 5 kabupaten induk di Provinsi Jambi tahun 2012 - 2016 karena prob t-statistik sebesar $0.0976>0.05$ alfa dengan signifikansi 95 persen, dan variabel PAD berpengaruh signifikan terhadap belanja daerah pada 5 kabupaten induk di Provinsi Jambi tahun 2012 - 2016 karena prob t-statistik sebesar $0.0095<0.05$ alfa dengan signifikansi 95 persen. Dari hasil estimasi dengan menggunakan Random Effect Model dapat dijelaskan bahwa masing - masing Provinsi memiliki nilai intersep yang berbeda - beda. Individual effect dapat dilihat dari tabel berikut ini: 
Tabel 20. Koefisien intersep Kabupaten/Kota hasil estimasi model

\begin{tabular}{lc}
\hline Kabupaten/Kota & Random Effect Model \\
\hline Bungo & 0.045511 \\
Merangin & 0.001201 \\
Kerinci & 0.001541 \\
Batanghari & 0.005412 \\
Tanjab Barat & 0.000044 \\
\hline
\end{tabular}

Sumber : Data diolah, 2019

Berdasarkan Tabel 20 tersebut dapat dapat dijelaskan bahwa jika terjadi perubahan pertumbuhan ekonomi, jumlah penduduk, dan PAD baik antar daerah maupun antar waktu maka Kabupaten Bungo akan mendapatkan pengaruh random effect terhadap terhadap belanja daerah pada 5 kabupaten induk di Provinsi Jambi tahun 2012 - 2016 sebesar 0.045511 rupiah. Apabila Kabupaten Merangin terjadi perubahan pertumbuhan ekonomi, jumlah penduduk, dan PAD baik antar kabupaten maupun antar waktu, maka akan mendapatkan pengaruh random effect terhadap terhadap belanja daerah pada 5 kabupaten induk di Provinsi Jambi tahun 2012 - 2016h sebesar 0.001201 rupiah.

Jika di Kabupaten Kerinci terjadi perubahan pertumbuhan ekonomi, jumlah penduduk, dan PAD baik antar kabupaten maupun antar waktu, maka Kabupaten Kerinci akan mendapatkan pengaruh random effect terhadap terhadap belanja daerah pada 5 kabupaten induk di Provinsi Jambi tahun 2012 - 2016 sebesar 0.001541 rupiah. Apabila di Kabupaten Batanghari terjadi perubahan pertumbuhan ekonomi, jumlah penduduk, dan PAD baik antar kabupaten maupun antar waktu, maka Kabupaten Batanghari akan mendapatkan pengaruh random effect terhadap terhadap belanja daerah pada 5 kabupaten induk di Provinsi Jambi tahun 2012 - 2016 sebesar 0.005412 rupiah.

Apabila Kabupaten Tanjung Jabung Barat terjadi perubahan pertumbuhan ekonomi, jumlah penduduk, dan PAD baik antar kabupaten maupun antar waktu, maka akan mendapatkan pengaruh random effect terhadap terhadap belanja daerah pada 5 kabupaten induk di Provinsi Jambi tahun 2012 - 2016 sebesar 0.000044 rupiah.

\section{Pengaruh pertumbuhan ekonomi terhadap belanja daerah}

Pertumbuhan ekonomi tidak berpengaruh signifikan terhadap belanja daerah dikarenakan oleh syarat untuk pembangunan ekonomi adalah tingkat pengadaan modal pembangunan yang seimbang dengan pertambahan penduduk. Bertambahnya insfrastruktur dan perbaikannya oleh pemerintah daerah diharapkan akan memacu Pertumbuhan Ekonomi daerah. Biasanya bila Pertumbuhan Ekonomi suatu daerah baik, maka pemerintah daerah setempat akan terus meningkatkan alokasi Belanja Modalnya dari tahun ke tahun guna melengkapi dan memperbaiki sarana dan prasarana, tetapi disesuaikan dengan kondisi dan situasi pada tahun anggaran.

Hasil penelitian ini sama dengan penelitian yang dilkukan oleh Deviani (2016),ia mengatakan hasil uji hipotesis terhadap ratio belanja modal memperlihatkan hasil yang tidak signifikan dengan arah hubungan yang positif pada pertumbuhan ekonomi. Pengeluaran pemerintah yang besar terutama pengeluaran konsumsi justru akan menurunkan pertumbuhan pendapatan perkapita.

Tujuan dari pembangunan ekonomi disetiap daerah adalah meningkatkan kesejahteraan masyarakat (social's walfare), yang salah satunya tercermin dari Kenaikan pendapatan perkapita dan meningkatnya pertumbuhan ekonomi yang di ukur dari 
kenaikan Produk Domestik Bruto (PDB) perkapita serta di barengi dengan usaha menekankan laju pertumbuhan penduduk, menurunkan angka inflasi, meningkatkan produksi, dan nilai tambah produk sektoral (Rosmeli, 2014).

Pertumbuhan Ekonomi adalah proses kenaikan output perkapita. Desentralisasi memberikan dampak yang sangat berarti bagi Pertumbuhan Ekonomi suatu daerah. Dengan adanya pengaruh yang signifikan antara desentralisasi fiskal dengan Pertumbuhan Ekonomi maka pemberian otonomi yang lebih besar akan memberikan dampak yang lebih besar bagi Pertumbuhan Ekonomi. Otonomi daerah mendorong pemerintah daerah untuk mempercepat terwujudnya kesejahteraan masyarakat melalui peningkatan pelayanan, pemberdayaan dan peran serta masyarakat.

Pemerintah memiliki peran yang penting dalam pembangunan daerah, dengan mengemukakan sejumlah faktor yang mempengaruhi pembangunan daerah. Faktorfaktor tersebut adalah sumber daya alam, tenaga kerja, investasi modal, kewirausahaan, transportasi, komunikasi, komposisi sektor industri, teknologi, pasar ekspor, situasi perekonomian internasional, kapasitas pemerintah daerah, pengeluaran pemerintah dan dukungan pembangunan. Tetapi, perbedaan kemampuan daerah yang satu dengan yang lain dalam mengelola potensi lokalnya dan ketersediaan sarana dan prasarana serta sumber daya menyebabkan Pertumbuhan Ekonomi antara satu daerah dengan daerah yang lain berbeda-beda.

\section{Pengaruh jumlah penduduk terhadap belanja daerah}

Penduduk memiliki pengaruh signifikan terhadap belanja daerah, hal ini karena jumlah Penduduk juga mempengaruhi Belanja Daerah. Pertumbuhan penduduk bukanlah suatu masalah, melainkan sebaliknya justru merupakan unsur penting yang berdampak positif dan bermanfaat bagi pembangunan ekonomi. Penambahan penduduk yang tinggi yang diiringi dengan perubahan teknologi dan pemberdayaan manusia akan banyak bermunculan ide-ide baru dan tenaga ahli.

Jumlah dan laju pertumbuhan penduduk adalah indikator kependudukan yang menjadi isu penting dalam pembangunan ekonomi. Tingginya laju pertumbuhan penduduk akan berimplikasi terhadap perencanaan pembangunan yang berkaitan dengan pemenuhan kebutuhan dasar, pendidikan, kesehatan dan infrastruktur yang berdampak terhadap besarnya pengeluaran pemerintah untuk membiayai pembangunan guna dapat meningkatkan pendapatan penduduk.

Pertumbuhan penduduk merupakan keseimbangan yang dinamis antara kekuatan yang menambah dan kekuatan yang mengurangi jumlah penduduk. Pertumbuhan penduduk diakibatkan oleh empat komponen yaitu kelahiran (fertilitas), kematian (mortalitas), migrasi masuk, dan migrasi keluar (Subri, 2013). Pertumbuhan penduduk dihubungkan dengan belanja daerah dianggap sebagai faktor positif dalam merangsang pendapatan. Sebab, meningkatnya jumlah penduduk akan meningkatkan pendapatan dan meningkatnya pendapatan akan meningkat pula pengeluaran yang dikeluarkan oleh pemerintah

\section{Pengaruh pendapatan asli daerah terhadap belanja daerah}

Pendapatan asli daerah berpengaruh secara signifikan terhadap belanja daerah. Menurut Mardiasmo (2002), pendapatan asli daerah adalah penerimaan yang diperoleh dari sektor pajak daerah, retribusi daerah, hasil perusahaan milik daerah, hasil pengelolaan kekayaan daerah yang dipisahkan dan lain-lain pendapatan asli daerah yang sah. Desentralisasi fiskal memberikan kewenangan kepada daerah untuk mengurus dan 
mengatur semua urusan pemerintahan dengan membuat kebijakan daerah untuk memberi pelayanaan, peningkatan peran serta, prakarsa dan pemberdayaan masyarakat setempat yang bertujuan untuk peningkatan kesejahteraan masyaraka.

Kemampuan daerah untuk menyediakan sumber-sumber pendapatan yang berasal dari daerah sangat tergantung pada kemampuan merealisasikan potensi ekonomi daerah setempat menjadi bentuk-bentuk kegiatan ekonomi yang mampu menciptakan penerimaan daerah untuk membiayai pembangunan tersebut. Daerah yang ditunjang dengan sarana dan prasarana memadai akan berpengaruh terhadap tingkat produktivitas masyarakat dan akan menarik investor untuk menanamkan modalnya pada daerah tersebut dan pada akhirnya akan meningkatkan Pendapatan Asli Daerah.

Menurut Halim (2007) dalam hal pengeluaran pemerintah daerah akan disesuaikan dengan perubahan dalam penerimaan pemerintah daerah atau perubahan pendapatan terjadi sebelum perubahan pengeluaran. Dalam literatur ekonomi dan keuangan daerah, hubungan Pendapatan dan Belanja Daerah didiskusikan secara luas sejak akhir dekade 1950-an dan berbagai hipotesis tentang hubungan diuji secara empiris menyatakan bahwa pendapatan mempengaruhi belanja. Berdasarkan penelitian sebelumnya dana perimbangan memiliki pengaruh terhadap belanja daerah, dimana pengaruh tersebut memiliki pengaruh yang positif.

Melihat beberapa hasil penelitian di atas telah menunjukkan bahwa PAD merupakan sumber pendapatan penting bagi sebuah daerah dalam memenuhi belanjanya. PAD ini sekaligus dapat menunjukkan tingkat kemandirian suatu daerah. Semakin banyak PAD yang di sapat semakin memungkinkan daerah tersebut untuk memenuhi kebutuhan belanjanya sendiri tanpa harus tergantung pada pemerintah pusat, yang berarti ini menunjukkan bahwa pemerintah daerah tersebut telah mampu untuk mandiri, dan begitu juga sebaliknya (Rahmawati,2010). Berdasarkan penelitian yang ada sebelumnya PAD berpengaruh positif terhadap belanja daerah. Jadi meningkatnya PAD yang didapat semakin tinggi daerah tersebut untuk memenuhi kebutuhan belanjanya. Sumber pendapatan daerah berupa Pendapatan Asli Daerah (PAD) berpengaruh terhadap belanja daerah secara keseluruhan. Meskipun proporsi PAD maksimal hanya sebesar $10 \%$ dari total pendapatan daerah, kontribusinya terhadap pengalokasian anggaran cukup besar terutama bila dikaitkan dengan politis.

\section{KESIMPULAN DAN SARAN}

\section{Kesimpulan}

Berdasarkan hasil olahan data untuk model pertama melihat pengaruh pertumbuhan ekonomi terhadap belanja daerah, maka ditemukan bahwa pertumbuhan ekonomi tidak berpengaruh signifikan terhadap belanja daerah pada 5 Kabupaten induk di Provinsi Jambi tahun 2012-2016, dengan menggunakan model yang terbaik adalah model FEM. Untuk model yang kedua melihat pengaruh jumlah penduduk terhadap belanja daerah dapat dilihat bahwa hubungannya positif dan signifikan di 5 Kabupaten induk di Provinsi Jambi tahun 2012-2016 dengan menggunakan model FEM yang terbaik. Pada model yang ketiga untuk melihat pengaruh PAD terhadap belanja daerah, ditemukan bahwa PAD berpengaruh positif dan signifikan terhadap belanja daerah pada 5 Kabupaten induk di Provinsi Jambi pada tahun 2012-2016 dengan menggunakan model FEM. Untuk model yang keempat guna melihat pengaruh pertumbuhan ekonomi, jumlah penduduk, dan PAD terhadap belanja daerah, secara bersama - sama terdapat pengaruh yang positif dan signifikan antara pertumbuhan ekonomi, jumlah penduduk, dan PAD terhadap belanja daerah pada 5 kabupaten induk di Provinsi Jambi tahun 2012 - 2016. Sedangkan 
pada uji secara parsial hanya pendapatan asli daerah yang berpengaruh signifikan terhadap belanja daerah pada 5 kabupaten induk di Provinsi Jambi tahun 2012 - 2016. Sedangkan pertumbuhan ekonomi dan jumlah penduduk tidak berpengaruh signifikan terhadap belanja daerah pada 5 kabupaten induk di Provinsi Jambi tahun 2012 - 2016.

\section{Saran}

Sebaiknya pemerintah daerah memberikan kebijakan umum pada aspek Birokrasi dan Pelayanan Umum diarahkan kepada meningkatkan kualitas perencanaan dan pengelolaan daerah, penataan dan peningkatan fungsi kelembagaan pemerintah daerah/ pemerintahan desa, peningkatan akuntabilitas dan transparansi kinerja pemerintah daerah serta peningkatan kualitas pelayanan publik. Arah kebijakan umum ini ditempuh melalui meningkatkan peran serta masyarakat dalam perencanaan daerah, meningkatkan kinerja aparatur dalam perencanaan pembangunan daerah, pengelolaan keuangan/aset daerah dan meningkatkan akses pelayanan publik, pemberdayaan pemerintahan desa/ kelurahan serta optimalisasi fungsi legislatif. Untuk meningkatkan alokasi belanja daerah maka pemerintah daerah diharapkan bisa mampu menggali sumber-sumber Pendapatan Asli Daerah baik secara intensifikasi maupun ekstensifikasi untuk meningkatkan pendapatan daerah. Dan pemerintah mesti objektif dan selektif dalam pelaksanaan belanja langsung Untuk meningkatkan alokasi belanja daerah maka pemerintah daerah diharapkan bisa mampu menggali sumber-sumber Pendapatan Asli Daerah baik secara intensifikasi maupun ekstensifikasi untuk meningkatkan pendapatan daerah, agar sesuai dengan yang diharapkan masyarakat. Meningkatkan alokasi belanja daerah maka pemerintah diharapkan bisa mampu menggali sumber-sumber Pendapatan Asli Daerah baik secara intensifikasi maupun ekstensifikasi untuk meningkatkan pendapatan daerah, demikian juga pemerintah daerah agar terus mengupayakan untuk dapat bisa menarik Dana Alokasi Umum untuk dialokasikan pada sektor publik seperti pendidikan, penyediaan lapangan pekerjaan serta modal bagi masyarakat agar penggunaanya menjadi efisien dan menjadi penerimaan daerah dan pemerintah mesti objektif dan selektif dalam pelaksanaan belanja langsung agar sesuai dengan yang di harapkan masyarakat setempat untuk meningkatkan kesejahteraan masyarakat di Provinsi Jambi. Sebaiknya pemerintah daerah lebih transparan dalam penggunaan belanja langsung yang lebih produktif. Sehingga dengan ada peningkatan belanja langsung memberikan dampak yang besar terhadap peningkatan pertumbuhan ekonomi di Provinsi Jambi.

\section{DAFTAR PUSTAKA}

Deviani. (2016). Analisis belanja daerah terhadap pertumbuhan ekonomi dan Pendidikan (studi empiris Kota dan Kabupaten di Sumatera Barat). Pekbis Jurnal, 8(1), 1-13.

DK Simanjuntak, S Rahmadi.(2016).Analisis pengaruh belanja modal, PMA dan angkatan kerja terhadap PDRB di Provinsi Jambi, E-Jurnal Ekonomi Sumberdaya dan Lingkungan, 5 (3)

DK Simanjuntak, S Rahmadi.(2016).Analisis pengaruh belanja modal, PMA dan angkatan kerja terhadap PDRB di Provinsi Jambi, E-Jurnal Ekonomi Sumberdaya dan Lingkungan, 5 (3)

Elita. (2007). Penerimaan penerimaan pendapatan asli daerah. Rajawali : Jakarta

Halim, Abdul. (2007). Akuntansi sektor publik : akuntansi keuangan daerah. Salemba: Jakarta.

Mardiasmo. (2002). Otonomi dan manajemen keuangan daerah. Andi : Yogyakarta. 
Pambudi, Triwidodo. (2007). Flypaper effect pada dana alokasi umum (dau) dan pendapatan asli daerah (PAD) terhadap belanja daerah pada Kabupaten/Kota di Bali. Skripsi. Fakultas Ekonomi Universitas Islam Indonesia :Yogyakarta.

Rahmawati, Indah. (2010). Pengaruh pendapatan asli daerah (PAD) dan dana alokasi umum (DAU) terhadap alokasi belanja daerah (studi pada pemerintah Kabupaten/Kota di Jawa Tengah). Skripsi. Universitas Diponegoro: Semarang.

Rosmeli. (2014). Dampak belanja daerah terhadap ketimpangan antar daerah di Provinsi Jambi. Jurnal Paradigma Ekonomika, 9 (1), 85-93.

S Rahmadi, M Safri. (2014).Peningkatan Belanja Modal dan Hubungannya terhadap Peningkatan Belanja Aset dan PAD Provinsi Jambi, Jurnal Paradigma Ekonomika, 9 (1)

S Rahmadi, M Safri. (2014).Peningkatan Belanja Modal dan Hubungannya terhadap Peningkatan Belanja Aset dan PAD Provinsi Jambi, Jurnal Paradigma Ekonomika, 9 (1)

Saragih, Panglima Juli. (2003). Desentralisasi fiskal dan keuangan daerah dalam otonomi. Ghalia Indonesia: Jakarta.

Subri, Mulyadi. (2013). Ekonomi sumber daya manusia. PT Raja Grafindo Persada: Jakarta.

Sukirno, Sadono. (2006). Ekonomi pembangunan (proses, masalah, dan dasar kebijakan). Kencana : Jakarta.

Widarjono, Agus. (2009). Ekonometrika pengantar dan aplikasinya Edisi Ketiga. Ekonisia: Yogyakarta. 